First Peoples Child \& Family Review

A Journal on Innovation and Best Practices in Aboriginal Child Welfare Administration,

Research, Policy \& Practice

\title{
Kinosao Sipi Minisowin Agency: Creating a Community Response for Special Needs Children
}

\section{Charlene Ducharme, Doreen Muskego, Alfred Muswagon, Clarence Paupanekis, Mike Muswagon, Walter Spence and Jacqueline Ramdatt}

Volume 3, Number 3, 2007

URI: https://id.erudit.org/iderudit/1069393ar

DOI: https://doi.org/10.7202/1069393ar

See table of contents

Publisher(s)

First Nations Child and Family Caring Society of Canada

ISSN

1708-489X (print)

2293-6610 (digital)

Explore this journal

Cite this article

Ducharme, C., Muskego, D., Muswagon, A., Paupanekis, C., Muswagon, M., Spence, W. \& Ramdatt, J. (2007). Kinosao Sipi Minisowin Agency: Creating a Community Response for Special Needs Children. First Peoples Child \& Family Review, 3(3), 12-20. https://doi.org/10.7202/1069393ar

\section{Article abstract}

The Children's Special Services program was created by the Kinosao Sipi Minisowin Agency to meet the requirements of special needs children and their families in the Norway House Cree Nation community of Manitoba. While the program itself is an excellent resource, its creation highlights the challenges faced by Aboriginal children with special needs and their families in regards to accessing services. Specifically, the creation of the program draws attention to the service vacuum that Aboriginal children with special needs must face. The value of the program to thecommunity cannot be underestimated as due to its existence, fewer parents have to make the choice of either placing their children in foster care or moving from their community in order to access services.
Copyright (c) Charlene Ducharme, Doreen Muskego, Alfred Muswagon, Clarence Paupanekis, Mike Muswagon, Walter Spence, Jacqueline Ramdatt, 2007
This document is protected by copyright law. Use of the services of Erudit (including reproduction) is subject to its terms and conditions, which can be viewed online.

https://apropos.erudit.org/en/users/policy-on-use 


\title{
Kinosao Sipi Minisowin Agency: Creating a Community Response for Special Needs Children
}

\author{
Charlene Ducharme ${ }^{a}$, Doreen Muskego ${ }^{a}$, Alfred Muswagon ${ }^{a}$, \\ Clarence Paupanekis ${ }^{a}$, Mike Muswagon ${ }^{a}$, Walter Spence ${ }^{\mathrm{a}}$ and Jacqueline Ramdatt ${ }^{\mathrm{b}}$
}

\begin{abstract}
${ }^{a}$ Kinosao Sipi Minisowin Agency, Norway House Cree Nation, MB ${ }^{b}$ Formally with the First Nations Child \& Family Caring Society of Canada, ON
\end{abstract}

\section{Introduction}

According to the National Population Health Survey, there were approximately 564, 575 Canadian children and youth between birth and 19 years of age with disabilities in 1996-97 (CICH, 2000). Among Aboriginal $^{1}$ Canadians, $22 \%$ of youth between the ages of 15-24 are reported to have a disability -three times higher than that of non-Aboriginal Youth (Demas as cited by Hanvey, 2002). Today, most children with disabilities live at home with their families as opposed to being placed in institutions as they were for most of the 20th century (Valentine, 2001). Unfortunately, this notable change does not mean that disabled children are full and active members within their communities. Despite the policy attention directed to children in recent years, children with disabilities have at times been excluded and the particular needs of their parents overlooked; for First Nations $^{2}$ children and families the situation is even more prominent (Valentine, 2001). Access to sources of support such as disability support services, health services, equipment, home care, education, child care and recreation are just some of the challenges faced by special needs children and their families (Hanvey, 2002). For those living in remote, poorly resourced communities the difficulties are even greater. In this sense, First Nations children on reserve are particularly vulnerable; and although there are a large number of Aboriginal children affected by disability,

\begin{abstract}
The Children's Special Services program was created by the Kinosao Sipi Minisowin Agency to meet the requirements of special needs children and their families in the Norway House Cree Nation community of Manitoba. While the program itself is an excellent resource, its creation highlights the challenges faced by Aboriginal children with special needs and their families in regards to accessing services. Specifically, the creation of the program draws attention to the service vacuum that Aboriginal children with special needs must face. The value of the program to the community cannot be underestimated as due to its existence, fewer parents have to make the choice of either placing their children in foster care or moving from their community in order to access services.
\end{abstract}

service delivery is consistently poor or non-existent in Aboriginal communities (Hanvey, 2002).

This paper will highlight the Children's Special Services program which was created by the Kinosao Sipi Minisowin Agency in response to the lack of support services for special needs children and their families within the community. The factors driving the creation of the program, conditions and indicators of success as well as challenges will be examined.

\section{Procedure}

The data for this article was gathered through a group interview conducted with Kinosao Sipi Minisowin Agency $^{3}$ (KSMA) staff members Doreen Muskego, Project Coordinator Special Services, Clarence Paupanekis, Executive Director, Charlene Ducharme, Assistant Executive Director, Alfred Muswagon, Term Program Coordinator and Norway House Cree Nation Councillor, Mike Muswagon. The meeting took place at KSMA head office in Norway House, Manitoba. 


\section{Background}

\section{Norway House Cree Nation Community}

Kinosao Sipi Minisowin Agency (KSMA) is a fully mandated child and family services agency responsible for ensuring that child and family services, as outlined in the Manitoba Child and Family Services Act, are carried out with the membership of the Norway House Cree Nation. One of the largest First Nations in Manitoba, Norway House has a population of almost 6000 (on and off reserve combined). The community has experienced a significant amount of infrastructure and community development since 1994 and is equipped with a number of amenities including a hospital and personal care home, two schools, churches, apartment buildings, public works facilities, a shopping mall and motel (Norway House Cree Nation, 2005). Culture and traditions such as Treaty and York Boat Days are important aspects of life in Norway House and these are celebrated throughout the year.

\section{Child Welfare Framework}

KSMA received its mandate in April 1999 with the signing of a tripartite agreement between the Child and Family Services Support Branch of the Province of Manitoba, the Department of Indian and Northern Affairs Canada, and the Norway House Cree Nation Chief and Council. Under this agreement KSMA is responsible for the provision of child and family services as governed by the Manitoba Child and Family Services Act. The agency's mandate was initially limited to First Nations members living on the Norway House Cree Nation reserve. However, the restructuring of the child welfare system within the province of Manitoba, under the 2003 Child and Family Services Act, has now provided the agency with a province-wide mandate. This expanded mandate means that KSMA is responsible for the provision of child and family services to status bearing Cree Nation members both on and off reserve throughout the province of Manitoba and has the authority to sign service agreements with other service providers to fulfill this function.

The restructuring of the child welfare system in Manitoba occurred through the implementation of the Aboriginal Justice Inquiry Child Welfare Initiative (AJI-CWI). The AJI-CWI is a joint initiative of the Manitoba Métis Federation, the Assembly of Manitoba
Chiefs, Manitoba Keewatinowi Okimakanak ${ }^{4}$, and the Province of Manitoba. This joint initiative was based on the recommendations of the 1991 report of the Aboriginal Justice Inquiry ${ }^{5}$ (AJI) which found that Aboriginal people were not well served by mainstream child and family service systems (AJICWI, 2001). The newly developed child welfare system acknowledges cultural differences and returns the right to develop and control the delivery of their own child and family services to First Nations and Métis peoples (AJI -CWI, 2003).

Under the new system which came into effect in May 2005, the delivery of child and family services is a more shared responsibility between the Province and Aboriginal peoples with the proclamation of the Child and Family Services Authorities Act in November 2003. Aboriginal children and families now have access to child and family services under the auspices of Aboriginal Authorities/Agencies no matter where they live in the province of Manitoba (AJI-CWI, 2003). This is accomplished through the delegation of responsibility for the delivery of child and family services from the Province to four new child and family services Authorities: Métis Child and Family Services (CFS) Authority, First Nations South Child and Family Services (CFS) Authority, First Nations North Child and Family Services (CFS) Authority and the General Child and Family Services (CFS) Authority (AJI-CWI, 2003).

Each community-based child and family service agency in the province is accountable to one of the four province-wide Child and Family Services Authorities. KSMA is affiliated with the First Nations North CFS Authority. The Northern Authority is responsible for the executive management of the service delivery system for First Nations of northern Manitoba while its affiliated agencies are responsible for direct service within the communities (First Nations of Northern Manitoba Child and Family Services Authority, 2006).

It is believed that all Manitobans will benefit from this new approach which respects culturally appropriate services (AJI-CWI, 2001).

\section{The Practice Context}

All children have the right to enjoy a full and decent life. As articulated by Article 23 of the United Nations Convention on the Rights of the Child (CRC), 
not only do disabled children have the right to a full and decent life, they are also entitled to conditions which ensure dignity, promote self-reliance and facilitate active participation in the community; States Parties are urged to recognize the right of disabled children to special care and services as well as assistance for children and their caregivers. Recognized by the Supreme Court of Canada as one of the most universally accepted human rights instruments in history, the CRC was ratified ${ }^{6}$ by Canada in 1991 (Shanner, 2003). However, despite this commitment on behalf of federal and provincial governments, the federal Standing Committee on Human Rights and Disabled Persons observed that both levels of government appeared to have forgotten the needs of Aboriginal people noting the fragmentation of services, lack of strong program structures and inconsistent standards (Canada House of Commons 1993 as cited by Hanvey, 2002).

Community supports for Aboriginal children are of particular concern as accessing community-based services is even more difficult for those residing in remote or rural areas. Given that at least $72 \%$ of Aboriginal youth live in small rural communities ${ }^{7}$, children and adolescence with special needs do face unique challenges. "Children and adolescence with special needs in rural and northern communities are extremely underserved and their needs poorly represented in policy and services derived from large metropolitan populations" (Centre for Excellence for Children and Adolescents with Special Needs, 2002).

Kinosao Sipi Children's Special Services was created to meet the service needs of physically and developmentally disabled children living on reserve. Prior to the Children's Special Services program, there were no therapeutic services available on reserve for children with special needs or support, educational or otherwise, for families caring for children with complex medical needs. While disabled individuals 18 years of age and older resident on reserve are able to access home support services through the local health care provider, children with disabilities, including those with complex medical needs, are automatically referred to KSMA for services.

Accommodating these referrals posed very real challenges for KSMA. As a child welfare provider, the agency did not have the resources or medical/ health training to respond to the, at times, complex medical needs of the children being referred. The agency also experienced pressure from family doctors and other professionals, who unaware of the service situation on reserve, would send letters filled with recommendations and suggestions for care based on urban expectations and accompanying resource base.

The availability of funds to develop a program to meet the needs of children and their families was also a challenge as KSMA does not receive funding for special services under its federal funding agreement, Directive 20-18. Under this agreement, KSMA receives funding through two major categories known as operations and maintenance. Operational funding is based on the population of Status Indian ${ }^{9}$ children resident on reserve in the $0-18$ age group and is intended to support the administrative functioning of the agency for salaries, travel, insurance and operational expenditures. Maintenance funds are provided on a reimbursement basis and cover costs related to placing children in care. Without designated funds to create programs to meet the service requirements of special needs children and their families, KSMA initially tried to respond to this service gap by using funds from its operations budget. This arrangement, however, created pressure on other service areas within the agency and could not be sustained. Without adequate funds to support the delivery of these much needed services, KSMA had to turn away up to 22 families seeking assistance.

Understanding the service gaps for First Nations children and families on reserve might better be understood when viewed in the context in which Aboriginal people receive health and social services in Canada. Aboriginal people receive services through a unique blend of federal, provincial and Aboriginalrun services as well as other programs and services (FNCFCS, 2005). The federal government provides services to Inuit and to status Indians on reserve. Health services are provided by Health Canada through the First Nations Inuit Health Branch and funding for child welfare services are provided by the Department of Indian and Northern Affairs Canada (INAC). Provincial and territorial governments provide services to Métis, status and non-status Indians living off reserve.

Given the complexity of this service matrix, jurisdictional conflicts often do arise. Provincial governments have refused to provide services for Aboriginal people on reserve and the federal 
government does not provide all the required services (Hanvey, 2002). These are long standing disputes between governments regarding who is responsible for the care of children. According to a recent report, 12 First Nations Child and Family service agencies experienced a total of 393 jurisdictional disputes in a one year period which required an average of 54.25 person hours per incident to resolve (FNCFCS, 2005)

The situation in which a special needs child is referred to agencies such as KSMA often occurs in the following manner: A family initially tries to obtain services for their special needs child through the federal health care provider on reserve which delivers primary health care services. Through Health Canada's Non-Insured Health Benefits program, coverage is available for a specified range of drugs, dental care, vision care, medical supplies and equipment, short-term crisis intervention, mental health counseling and medical transportation (Health Canada, 2005). The full service requirements of special needs children which may include, in home support, special equipment, long-term occupational, speech and physical therapy may not fall within the spectrum of services provided. Children are then by default referred to the local child and family service agency, which is funded by the Department of Indian and Northern Affairs Canada. The child welfare provider through taking the child into care is able to provide services under its maintenance budget which is then billed to INAC. Depending on the nature of the services provided, a jurisdictional dispute may ensue between the two federal departments (Health Canada and INAC) regarding which is fiscally responsible for the services rendered.

The limited and often lack of services on reserve had a direct impact on the lives of children and families in the Norway House Cree Nation community. In the absence of programs and services, families on reserve either placed their children in foster care or moved away from the community. By placing their child in foster care, which is covered under the KSMA maintenance budget, families are able to access some therapeutic equipment and services for their children ${ }^{10}$. Similar issues regarding the disruption of families in order to gain access to care was highlighted by the May 2005 Report of the Ontario Ombudsman which brought attention to the plight of Ontario families having to place their special needs children in care in order to access services (Marin, 2005).

Families who move off reserve are able to access provincially funded services. Having to leave the familiarity and traditional family support of a home community in order to access services is an undesirable choice, however, the contrast between the resources available in an urban centre and rural or remote community can be great. Kinosao Sipi Minisowin Agency Executive Director, Clarence Paupanekis, shared his own experience of this reality stating that his family did not become aware of the existence of in-home support services for children until living temporarily off reserve for educational purposes. While living in an urban centre, the family had access to a whole range of services and was able to receive in-home support services for their special needs child. These services, which were provided by the provincial government, did not follow the family when they returned to the reserve.

\section{The Kinosao Sipi Children's Special Services Program}

For an agency with a stated vision of 'fostering healthy family unity for the betterment of the Norway House Cree Nation' (KSMA, 2005), turning away families in need of assistance was intolerable. In order to address this critical service area, KSMA was able to successfully obtain funds by submitting a three year proposal to deliver a Children's Special Services Project from the Norway House Cree Nation Community Master Implementation Agreement Trust Fund. This is a fund to which members of the community can put forward proposals on a yearly basis for social or economic causes of benefit to the membership of the Norway House Cree Nation. Proposals are reviewed by the Trust Committee and Chief and Council in terms of available funds and are then subjected to a community approval and voting process in meetings attended by band members. KSMA was able to receive a $\$ 450,000$ per year grant to develop and deliver a program which would provide services for children with special needs on reserve for a period of three years.

The KSMA Special Services program supports families in caring for their children in a way that promotes family unity and community strength. The Kinosao Sipi Children's Special Services program, now in its second 
year of operation, provides individualized in-home support services through a tri-level delivery model which is child-centered, family focused and communitybased. Within the context of the program, special needs refers to a "disability, delay or health disorder which can be a physical or mental impairment that is anatomical (affecting bodily structure), physiological (affecting bodily functions) or a psychological abnormality (affecting the mind), or a combination which results in marked or severe functional limitations" (KSMA Special Services, 2005).

The goals of the program are to:

- Provide accessible services so that families with special needs children do not have to leave the community for service supports;

- Provide individualized In-Home Support Services;

- Improve the quality of life for all children with special needs by providing services to help them with the activities of daily living;

- Work with the whole family to ensure everyone is involved in the decision making process, thus empowering the family unit;

- Network with other resources (schools, hospitals, etc.,) in and out of the community;

- Educate families about disabilities to help strengthen the family's care capacities; and

- Promote awareness and education on the issues and challenges faced by children with special needs and their families.

In-home support services offered in the program include:

\section{Rehabilitative Therapy Services:}

- Speech therapy

- Occupational therapy

Case Managers who provide:

- Counselling and advocacy

- Networking and referral

- Assessments, coordination and monitoring of care plans, evaluations, home-visits and escort services

In Home Service Providers who:

- Are trained to meet the unique needs of each child
- Assist with household needs

- Interact with children in planned daily activities

- Provide therapy services as trained by professional therapists

In 2004, the program provided a number of workshops and presentations for parents and care givers as well as camps for children including (KSMA, 2005):

- Alternative forms of communication (sign language and picture exchange systems) workshop

- CPR and First Aid Training

- Dental Health - a mouth course for special needs children

- Promoting Literacy presentation

- Occupational Therapy Mini workshop

- ADHD(Attention Deficit Hyperactivity Disorder), ODD (Oppositional Defiance Disorder), and FASD (Fetal Alcohol Spectrum Disorder) presentations

- Self-care Training for service providers

- Summer Camp for Extra Special Kids

- Self-esteem Camp including bully prevention and drug and alcohol prevention workshops

The importance of this program for families and children in the community should not be underestimated. Prior to the program's establishment, families with children in need of specialized services either had to move off reserve whereby they qualified with the Provincial Children's Special Services Program for a wide range of services for the parents and children, or parents had to place their children under a voluntary placement agreement with child welfare authorities in order to receive services. The Kinosao Sipi Children's Special Services program helps to keep families together.

\section{Indicators of success}

The Special Services program has demonstrated considerable success since its implementation. The program has been able to meet the identified needs of children and families in the community for in-home support services, occupational therapy and speech and language therapy. Education which enables families to gain an understanding of the nature of their child's disorder is also provided. As a result, there has been a significant increase in the demand for program 
services and an increase in the number of families being served. One of the biggest indicators of success, however, is the gratitude and appreciation expressed by families and their strong support for the program's continuation. Some of the responses of families expressed in the Special Services Questionnaire are shared below:

\begin{abstract}
A lot of families desperately need these services. There is finally something here in Norway House. A lot offamilies cannot afford to relocate to receive respite, occupational services etc.

When I found out my daughter was borderline autistic, I was glad I had answers as to why she was so different but also disappointed because I couldn't go to anyone for help in my community. I had high hopes for my daughter and my only answer would be to move her away. Now that this service is provided I feel that I don't have to leave because there is a door opened for her here - that she's been given resources to meet her needs.
\end{abstract}

This program has really helped my child with understanding and respecting herself. And it really helps our family.

It [the program] has taken a lot of pressure and stress from us. We live a healthier life now. Our son is more outgoing and interactive with other kids.

Two additional indicators of great significance are that since the program's implementation, fewer families have had to leave the community in order to access services and children are no longer being placed with child welfare authorities as a means of receiving assistance. Within the context of community development, the program is a source of employment for a number of community members. The degree of staff retention is also a worthy signifier with the program experiencing very little staff turn-over. This is a substantial benefit for clients as it supports consistency in service provision.

The ability of a program to operate in congruence with organizational and community principles is also a significant indicator of success. In this regard, the program has been successful in engaging families and promoting the family unit - something which is conceived as a benefit for all Norway House Cree Nation children. A positive aspect of family and community engagement is the use of respite/support workers assisting the family and special needs child with family activities and/or participation in community events. The program utilizes community resources, of which families are identified as one of the most important, and in this way reflects and reinforces community values and beliefs of sharing and helping one another. The volunteer Parent Committee is another example of family and community engagement. This committee, consisting of parents who are currently involved with the Children's Special Services program, organizes monthly activities for children and families involved with the program. A modest budget is provided to assist the committee with setup activities.

It is important to note that there are some indicators of success which, though valuable, cannot be measured quantitatively. An example of such an indicator is the alleviation of stress and pressure on the family. Parents involved with the program have time for self-care and are no longer compelled to leave the workforce in order to stay home and provide care. These are factors which benefit the family as a whole and also function to improve parental selfesteem. The interest expressed by other Northern and Southern Manitoba communities to shadow the Special Services program is an indication that the program success is being noted.

\section{Conditions for success}

Undertaking a community needs assessment was cited as an essential condition for the success of the Special Services program. The community assessment (was) is a tool which can identify (identified) the nature and scope of community needs and actions which can be taken to address the issues as identified. An additional condition for success is hard-working, committed people to ensure proper implementation of the program. Strong advocacy skills and a political voice to raise awareness of issues, needs and negotiate solutions are also necessary. The philosophical underpinning of the program in terms of being child focused, family focused and communitybased, requires active involvement and engagement of families and the promotion of family unity which is seen as a benefit to all Norway House Cree Nation children. Finally, as the Children's Special Services program is a community-based initiative, community support for program development, funding and evaluation is required. Community support is 
sustained by ensuring transparency through monthly reports and an annual open house.

\section{Challenges}

Funding related challenges are the most common and pressing issues identified by KSMA staff in relation to the provision of services for children with special needs. Funding restraints are significant factors in terms of why the Special Services program was created, its current implementation and future sustainability. Restricted funding means that the program, ironically, cannot keep pace with its own success. The high number of clients being served and the program's fixed budget means that future clients may have to be turned away and/or the range of services provided curtailed in order to meet increasing demand. In actuality, this is already becoming a reality for the program; in the second year of implementation, cutbacks in services have already been made. The agency had initially been able to provide transportation and accompaniment services for children requiring out of community medical appointments and the program's previous capacity to assist parents to obtain therapeutic tools recommended for the children by professional services has diminished. Insufficient funding also means that KSMA is restricted in the populations of children which can be served. Although the agency would like to provide services for children with FASD, for example, this is not currently possible. The need for specialized personnel, such as a physiotherapist, to provide service to the children within the community, cannot be fiscally accommodated.

\section{Conclusion}

Through the use of community funds for program development, KSMA has been able to provide services for children with special needs and their families. While access to community financial resources for program development, implementation and evaluation was an option for KSMA, this is not the case for all First Nations child and family services agencies. Even for KSMA, this solution though successful, is a vulnerable one given the time limitations of program funding.

While the Children's Special Services program is a promising practice for which KSMA can be proud, the circumstances driving its creation does raise some troubling questions.
How is it that in a wealthy, modern nation there are children, families and communities that go without or are left with unsuitable choices? How is it that families who want to care for their disabled child either have to leave their community or surrender their child to child welfare authorities? The Kinosao Sipi Children's Special Services was created to fill a service vacuum created by governmental oversight and disputes essentially regarding fiscal responsibility for Aboriginal children.

It is fortunate for the children and families of the Norway House Cree Nation that they belong to a community which has found a way to respond to their needs. Communities need to be supported in this role while governments must come to terms with their responsibility for all children. In this regard, the following recommendations are made:

i. Federal and provincial government departments, particularly Indian and Northern Affairs Canada (INAC) should permanently fund programs such as those of Kinosao Sipi Children's Special Services on reserve that are comparable and equally funded as those that are available in urban centres such as Winnipeg with the fundamental principle of working with the community network to promote and enhance the child, family and community values, beliefs, customs, and culture.

ii. All stakeholders (CFS Agencies; First Nations/ Federal/Provincial governments; Non-Profit Agencies) assemble to create solutions for a mechanism to avoid any delays in service delivery.

iii. Programs such as the Kinosao Sipi Children's Special Services are substantial enough to be independently incorporated community resources which work collaboratively with other community health and social service providers.

The circle of caring needs to be expanded so that families are not faced with unsuitable choices and no child is made to live with the consequences of them.

\section{Endnotes}

1. Aboriginal is a term used to denote the original inhabitants of North America. Three separate groups of Aboriginal people are recognized under the Canadian Constitution: Indian, Métis and Inuit. It is important to recognize that these are separate peoples 
with unique heritages, cultural practices, languages and spiritual beliefs (INAC, 2004).

2. First Nation is a term which refers to Status and non-Status Indians in Canada. Although there is no legal definition for this term, it is widely used to replace the term Indian. First Nation is often used to replace the word 'band' in the name of a community (INAC 2002).

3. Norway House Family (child and family services) Agency.

4. Manitoba Keewatinowi Okimakanak is a political body that represents the interests of Northern Manitoba First Nations Communities.

5. Commissioned in 1988 to examine the relationship between the Aboriginal peoples of Manitoba and the justice system, the AJI included an assessment of the historical treatment of Aboriginal people by the child welfare system (AJI-CWI, 2001).

6. Having ratified the CRC, Canada is obliged to respect the rights of children articulated therein.

7. Centre of Excellence for Children and Adolescence with Disabilities (2002).

8. This funding is administered by the federal department of Indian and Northern Affairs Canada (INAC).

9. The term Status and non Status Indian are legal terms identifying an individual's legal status as an Indian as defined by the Indian Act.

10. Access to resources such as specialized foster homes or residential care facilities through the use of a voluntary placement agreement is also a restricted option as there is a limit regarding the number of times such an agreement can be entered into before the matter must then proceed through the courts in the form of a permanent order. Voluntary placement agreements are used for children ages 0-17 and end on the day the child turns 18 years of age (Section 14 Child and Family Services Act, 1985).

\section{References}

Aboriginal Justice Inquiry Child Welfare Initiative (August 2001). Promise of Hope: Commitment to Change. Child and Family Services in Manitoba. Winnipeg, Manitoba.

Aboriginal Justice Inquiry Child Welfare Initiative (March 2003). Summary of the Detailed Implementation Plan (DIP) for Restructuring the Child and Family Services System of Manitoba. Winnipeg, Manitoba.

Canadian Institute of Child Health (2000). The Health of Canada's Children: A CICH Profile. http://www.cich.ca/PDFFiles/ProfileFactSheets/ English/DisabilitiesEng.pdf.
Centre of Excellence for Children and Adolescents with Special Needs (February 2002). Revised Proposal. http://www.coespecialneeds.ca/PDF/ proposal.pdf.

Child and Family Services Act, C.C.CM. c. C80. Part II Services to Families. Voluntary placement agreement 14(1). S.M. $1985-86$.

First Nations Child and Family Caring Society of Canada (2005). Chapter 3. Jordan's Principle. Wen: de We are Coming to the Light of Day. Ottawa, ON

First Nations of Northern Manitoba Child and Family Services Authority (2006). http://www.mkonorth. com/northerncfs.HTML.

Hanvey, L. (2002) Children with Disabilities and their Families in Canada: A Discussion Paper. National Children's Alliance for the First National Roundtable on Children with Disabilities.

Health Canada (2005). First Nations \& Inuit Health. Non-Insured Health Benefits. http://www.hcsc.gc.ca/fnih-sobu/bugb-ssba/index_e.html.

INAC. (2004). Words First: An Evolving Terminology Relating to Aboriginal Peoples in Canada. Ottawa, ON: Communications Branch, Indian and Northern Affairs Canada. http://www.aincinac.gc.ca/pr/pub/wf/pdf e.HTML.

September 2004 Kinosao Sipi Minisowin Agency (2005). Year in Review - 2004. Norway House, $\mathrm{MB}$

Kinosao Sipi Children's Special Services (June 2005). Program Brochure. Norway House, Manitoba

Kinosao Sipi Minisowin Agency (2005). Program Description. Norway House, Manitoba

Marin, A. (May 2005). Between a Rock and a Hard Place: Parents forced to place their children with severe disabilities in the custody of Children's Aid Societies to obtain necessary care. Final Report. Ombudsman Ontario.

Norway House Cree Nation (January 2005). A New Beginning. Norway House, MB

Shanner, L. (2003). Legal Challenges to Donor Anonimity. Health Law Review, Vol. 11 No. 3. Health Law Institute University of Alberta. http:// 
www.law.ualberta.ca/centres/hli/pdfs/hlr/v11 3/06shannerfrm.pdf.

United Nations Convention on the Rights of the Child (1989).

Valentine, F. (2001). Enabling Citizenship: Full Inclusion of Children with Disabilities and their Parents. Canadian Policy Research Networks. Ottawa, ON. 